S:IITH, John E.

An essay on the development of the mouth parts of certain insects.

q(il.

434

564

18396

int. 



\section{An Essay on the Development of the Mouth Parts of Certain Insects.}

By JOHN B. S.IITH, Sc.D.

Read before the american Philosophical Society, February 21, 1896. 


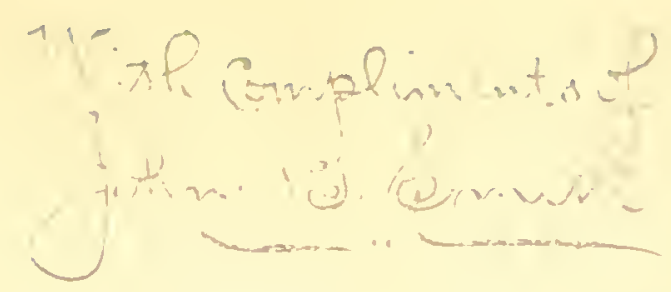

\title{
254657
}

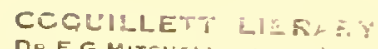

DR.E.g.Mitchell comón. ì

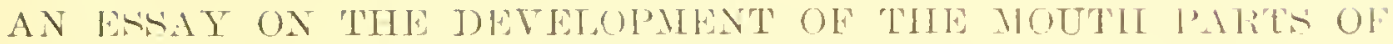
CHRTAN MNELTS.

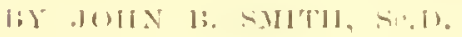

Read before the American Philosophical Society, Febı uary 21, 1896.

Since the publication of my papere an the month pats of the Diptere punted in

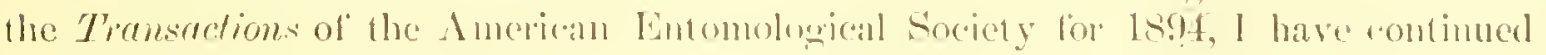

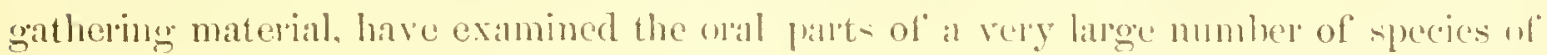

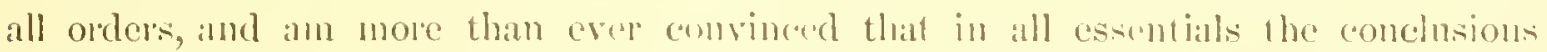
alveady published by ne are correct - revolutionary as they swem at fir-t -ight. 'That

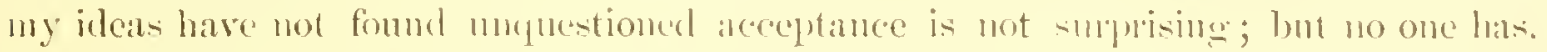
to my knowledge, puhlished anything that dispores the prints made by me. It has

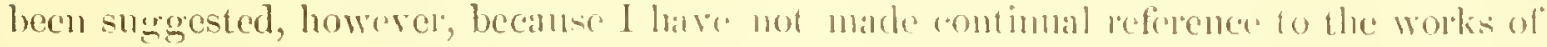

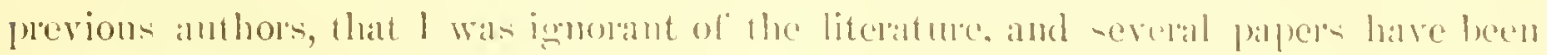

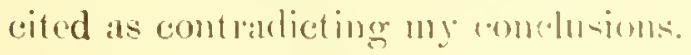

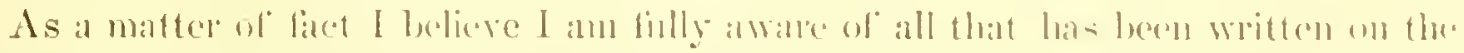

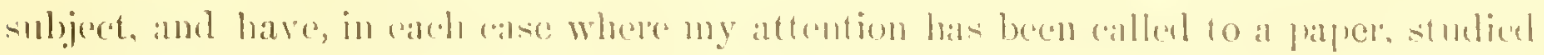

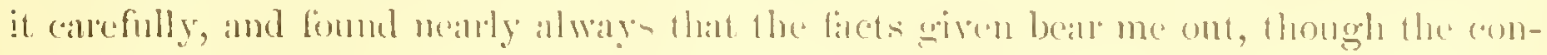

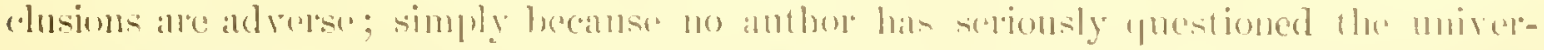

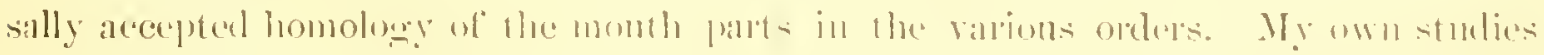

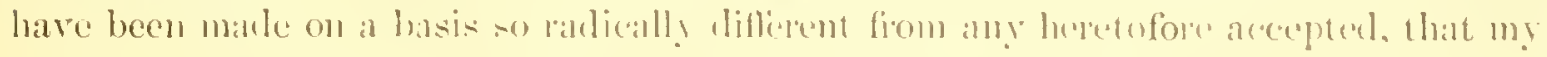

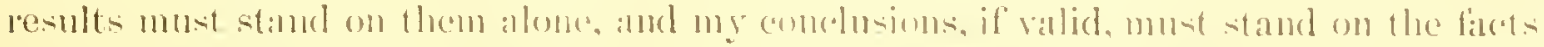

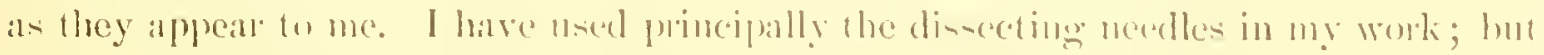

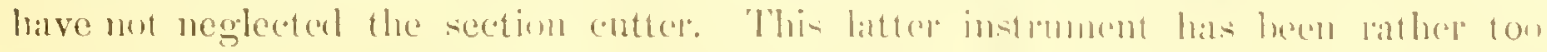

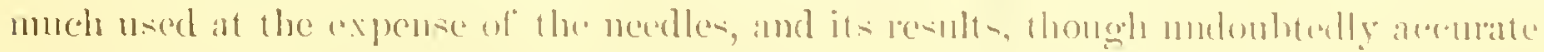

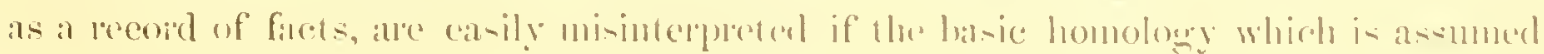


to exist is inaceurate. For the reasons junt given no references to previous writers will be made, except incidentally, and as I have in somse recpect modified my ricuas to the homology of certain of the parts, I will go into the cutile subject in such detail as is necessary to prove my point; but withont reprinting my lirst piner, which should be herewith consulted.

I do not expeet denial at this day, when i claim that no explanation of the homologies of the month parts of inserts an be considered satisfictory which will not stand the test of criticism by the theory of evolution. If we assume the origin of all insects from one original type, we must, neecsarily, assume that all the month structures are derivative of one type, and we must so study them as tu be able to explain, -tep by step, just what specializations hare oceured. We may not be able to complete entirely eated link in the chain of evidence, lut we ean, at any rate, reach a result consistent with all the firets known to us. Any explanation which satisfies all the requireunents of a regular and matural development is to be prefered to one which demands an unexplained specialization of any prat, not in line with its function in other series. It is therelore necessary to stndy carefully the make-up of every separate month organ, and of every selerite in each, to become thoroughly fimiliar with its nses and to ascertain the lines in which it varies or develops.

It may be premised that the month parts of the IIemiptere in their present condition are not included in the lange of these studies. I have examind numerons specimens and have devoted espeeial attention to Cicada and Thrips-the latter classed as hemipterons for present purposes only-and I believed at one time that I had made ont the remunts of a mandibular sclerite, and so published it. Mr. ('. L. Marlatt fuestioned my conclusions and asserted that the mandibles are represented by one pair of hristles. While I believe that I was wong in my identification of the mandibular selerite, I am yet convinced that I an correct in claiming that beak and setar are all maxillary strnctures. I have eonchnded, howerer, alter a careful review of all my preparations and of what has been written, that the Hemintera in the mouth structure are uot descended from any well-rleveloped mandibnlate type, and that no trace of true mandibular structure ocenrs in any present form.

In other words, the Ilemigtere equal all the other orters combined in rank, for all others are mandibulate or derivatives from a mandibulate type. The anchetypal Thysannman with undeveloped mouth organs varied in two directions-toward the haustellate type now perfeeted in our present IIrmiptera. and to the mandibulate type: and there has never sinee been any tendency toward a eombination. The haustellate type proved ill adapted for variation and ther is, in consecunence, a remarkable sameness throughont. This kind of strurture must be studied on an entirely new basis to 
get at the -teps by which the present "bak" was developed, and my material is not suflicient for that purpose. The mandibulate type, on the contrary, prored well adipted for variation, and its diflerenees and modifications alre bere tracerl.

For convenience, Kolbe's figures of the mouth parts of a grastropler are reprodneed on Pl. III, Fig. 22, and may be referred to in connection with the following explannation.

In a well-developed mandibulate mouth we have, forming an mpere lip, the labrum, often notched in front or toothed: but never a paired organ. never with alpendages, and never mechanical in function. It in articulated an bate th the rypeus and serves to -hield or protect the month in front; as a matter of fixct, not a functional mouth structure at all. It is marked $/ h \cdot$ in all figneres.

More or less intimatcly associated with it on the inner side is the eppipharyx, which is compared in function with the palate of rertebrates, and is fuminhed with -ensury hairs, pegs or pitting. It may be so chosely united with the labrum ats to form, practically. a part of it, or may be entirely free. If tree from the bibmon, the epipharys is more elosely united with the other mouth parts, and in such caser its smpurta go to the mentum or labial structures. Not inliequently it hat attachments to both. In form it may be a mere pointed process, or it may be a more or hess divided, plate-liki organ; but its fincefions are gustatory or sensory in all cilses-it never lecomes a functional meehanical strueture, and I have never found it withont al mole or less dereloped labrum to shich it. It is lettered opi in all figures.

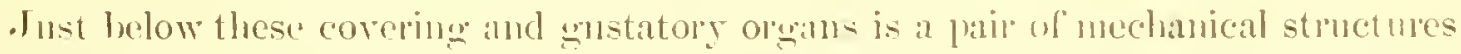
- the mandibles-set, one on each side of the head, and attached to the inferior maryin of the epicranium ol an extonsion from it. These mandibles alre nerer jointed, rately bear appembages, and never such as are functional, rarely halve a movalle tooth, and are usually solid and highly chitinized. They are actually made up of a number of

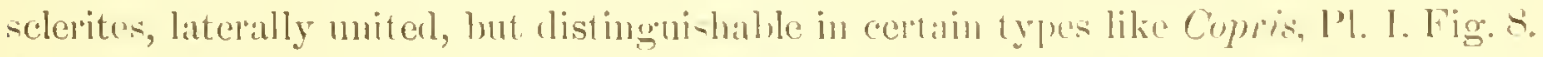
I have elewhere named and homologized these sclerites; but as the matter is ant in dispute, and of no inportanee here, a simple reference to the figne in which they ane named is all that is necessary. The position of this pail of mouth -tructure is invalriahle. They are completely disassociated from the maxillaty or lahial struetures and remain attareded to the head whell all the other parts are remored in a hody. They attach by socket joints to the epieranimo and their tendons and mu-elen attach to its immer surface. They never ahnge in finction, never become united with or attached to the other month organs and never become intermal struetures. When not needed for chewing or biting the tendency is to obsolsecence: never toward a change into a thrusting or piencing organ, so fall an my observations axtent. 
Below the mandibles are found a pair of maxillie, made 1 p in all cases of a mmber of sclerites, and nearly always supplied with palpi or jointed tactile organs. The more particular consideration of these organs and their parts may be somewhat deferred.

Forming the lower lip and closing the month inferiorly is the labium, also made up of a number of selerites and usually funished with palpi. It is never entircly paired in existing insects, but is assmmed to be made up of two more or less united structures, similar in essential character to the maxilla as has been well stated by Prof. J. IT. Comstock. This labium is an exeedingly important structure and forms the oral termination of the digestive tract or the month of the arsophagns.

Attached to the inner surface of the labinm is the hypopharynx, a variably developed structure, which is supposed to be the remmant of another originally paired organ, the endo-labium. I have never seen the genera in which it is said to be well developed, hence have no well-founded opinion to offer. I find it uniformly a single organ, often highly developed and gustatory in funetion, sometimes a merely passive -tructure more or less closely attached to the ligula, usually very near the opening into the digestive traet.

Briefly reeapitulated, the insect mouth, when most fully developed, consists of two pairs of lateral jaws moving in a horizontal plane between an npper and a lower lip, whieh are furnished with gustatory structures forming the roof and the floor of the month respectively. This mouth is adapted for biting and chewing and raries to types adapted to lapping, to sucking only, and to piercing and sucking. The problem before me is to ascertain by what modifieations these diflerent ehanges in type have beeome e-tablished.

If we examine the head of a well-developed mandibulate insect from the under side-Copris carolina, Pl. I. Fig. 7, may serve as type-we find, centrally, the gula or throat, bounded laterally by the gene or cheeks, extending to the posterior margin of the hear and bearing anteriorly the labinm. The labinm when earefully dissected out is found to consist of a broad hasil plate, the submentum, more or less firmly articnlated to the gula and never, in existing inseets, a paired organ. It bears anteriorly another plate, the mentum, also a mited organ, though sometimes traces of a dirision are apparent. It is usually smaller than the submentum, sometimes membranoms, often entirely separated and frequently so united with the latter part that the two are not separable. Thongh the submentum is the most persistent and dominant structure it has been enstomary to use the term mentum to apply to the mited sclerites, and it will become convenient for me to so use the term hereafter when no confusion or misunderstanding can ba occasioned. 'The structure is lettered $m$ in all the figures. 
Attached and articulated to the mentum anteriorly are the central ligulat, a pair of paraglossa bounding it, and a pair of palpigers, one at cach outer edge, learing the labial palpi.

The ligula or glossil, matred $g l$ in all the figmes, is a paired organ only in the more generalized orders. and is usually present as a single, centual structure, which maly be either chitinous and rigid or membranons and flexible. It is the most persistent of all the labial structures, is never attached except to the mentum, and allwas has associated with it the hypopharynx where that is present. We always find at its base the openimg into the alimentary canal, or asophagus, as this part of it is termed, and this must ever be the test of labial structures-that they are attached to the mentmu and have at their base the opening into the alimentary eamal. The assuciation is never broken, and the bare of the ligula, whatever its form or however it is modified, always marks thi- point. On the other hand, by tracing the allimentury camal to it-cxtermal opening, we can always recognize the lignla by its position, however little it may leesemble normal types.

The paraglosid are sometimes intimately mited with the ligula, -ometimes completely separated from it: they may be of the same or a dillerent texture; but the! always arise from the mentum on each -ide of and close to the central structure. Thurir tendency is to obsolesence. but they may become nuited and form a bed line the ligulit which remains the imner organ. Theil lange of variation is not great; they are mereve jointed, and nerer become mechanical structmes.

The palpi are tactile in function under all circmuntances, though they may lose this function in great part and may, by coalescence, finm a sheatluing to the ligntal. They ane nerer, muder any circumstances, attached anywhere except to the montum. directly or indrectly, and their locition must be constantly the -ime. They cimmot. without losing their ex-ential character, becone disissociated from the mentum. nor can they ever form an chrelope or corering for it, or for the sulmentum. without a change entirely at variance with any leasonable theory of derelopment. 'To accomplish this they would first lose their aharacter as hahial alpendiages. In Inicf, the lathum in the external beginning of the alimentan'y calnal, and mome of the parts eree lose this association. Whatever their modilieation, no labial -tmetures

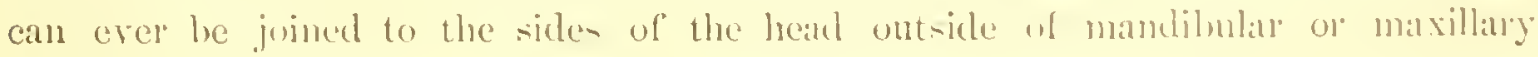
-tructures.

As an illustration of the mo-t generalized form of lishimm at fuesent limewn to

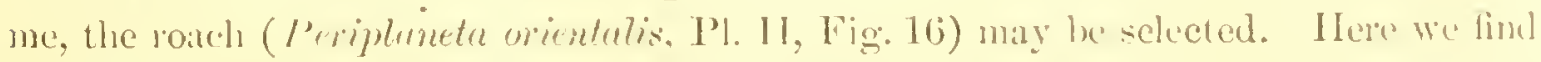

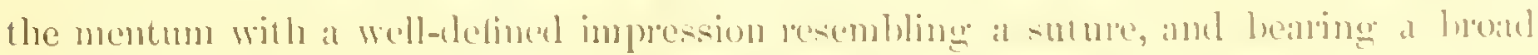

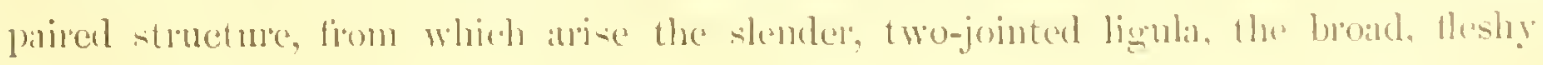


parraglossie, and the three-jointed labial palpi. This generalized structure fixes the relation of the pirts, and fiom it we may pass to more -pecialized types.

In Harpalus caliginoses ( PI. III, Fig. 7) we have a case where the ligula forms a single, central organ, laterally bounded and on one side completely enveloped by the softer paraglossie. The location of the palpi remains essentially the same. We have here two cases showing the ehange of a two-jointed membranous paired organ into a single, rigid, chitinons structure, and the identity of the part is not questioned, nor I beliere, questionable.

If we carry our dis-ection one step further and from the fresh specimen remove not only the highly chitinized part, but also the softer attached strnetures, learing maxille and mandibles undisturbed, we find in all cares the wophlogus in the cavity below the mentum and :ubmentum, and these sclerites afford attachments for nece-r-ary muscles. They also form, by means of chithons extensions and processes, a chamber or earity protecting the esophagus and supplying muscular attachments when a sncking or pumping structure is needed. Thus the mentum and submentum, whether separated or united, are always inferior coverings to the cesophagus. 'To support this structure, processes sometimes extend almost or quite to the upper or anterior surfice of the head, and in many cases, where the epipharynx is separated from the labium, it is comnected by means of long processes with the mentum. This is true in many Coleoptera, quite usual in the Hymenoptera, and oceasionally found also in the Diptera. In Pl. I, Fig. 6, is a lateral view of the labium of Copris carolina when completely dissected out, and the clubbed processes, loosely attached to the inferior prolongation of the submentum, normally support the epipharynx. In Pl. I, Fig. 9, and Pl. II, Fig. 18, we note similar processes in Andrend vicina with part of the epipharynx still attached, and in rolistes metricus, where the structures are complete. Precisely the same structures occur in Simulium (PI. I, Fig. $1^{t}$ ), as will be more fully noted hereafter. It may be stated that I have adopted the term "fulerum," used by Nacloskie and others, to designate the strueture formed by the mentum and sulmentum and containing the beginning of the alimentary eamal.

In l'olistes metricus (Pl. II, Fig. 18 ${ }^{b}$ ) I show the libinm completely dissected ont, with all its attachments, viewed laterally: It will be noted that here the mentum and submentum are united, highly chitinized, and form a scoop-shaped structure, bearing at one end the labial structures and enclosing normally the beginning of the resophagus. Attached by long chitinous rods to the posterior angles is the epipharynx, so that hypopharynx and epipharynx are bolne on the same base, are closely opposed to each other and may he manipulated by muscles arising close together. The

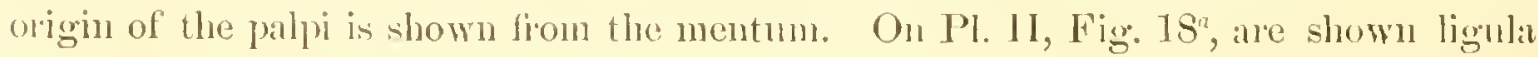


and paraglosse of this same l'olistes. The structures are here membranous, somewhat bladder-like, and well aldapted for lapping by means of thattened, bent processes, set in series on the entire inner surface. The paraglossic ance eompletely separated and the month opening is shown at the base of the fignre, as well as the chitinous ring marling the beginuing of the asoplagus.

In Andrend vicina (Pl. I, Fig. 9) we find a similar yet quite dillerent strueture, i. e., the same parts. used for much the same purpose, yet considerably modified in detail. The mentum is here much longer, more shallow, but similarly bears the epipharynx on chitinous rods. The ligula is more intlated and the paraglosint alle much reduced, but the palpi originate an before, and we have simply an illustration of the valiation in form found in thi- united mentum and submentum. It is important to note here that in /'olistes, Andrena, and indeed the Hymenoptera generally. the labial structures are free fiom all lateral attachments to the head and may sometimes be projeeted forward quite a distance. The attachment to the head, indeed, is museular and membranous entirely, and there is no direct articulation to any point ly chitinons or rigid processes. There is mothing therefore to prevent the growth of the head sclerites around the mentum, which would thus become an internal structure-as has actually laiplened in the Dipter:a.

Another feature upon which Dr. Packard rightly places great stress is that a salivary duet opens into the hypopharynx at the base of the ligula, which he thereby identifies. As this ligula is always attached to the mentum, it follows that this structure may be identitied in the same way, while no structures not originating from the same point can be labial in character.

Before studying further the specializations of the labial structures, it may be well

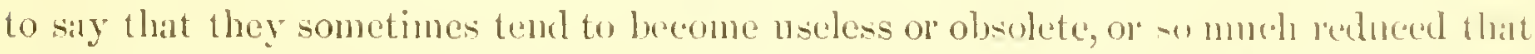
they are difficult of recugnition: and, entronsly enomgh, in such eases the palpi scem to be the persistent organs. T'hus in some species of Scolieder ammog the Hymenoptera the mentum bear's only litte, feebly developed palpi. I striking calse is in the

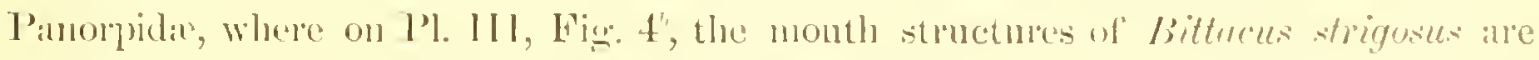

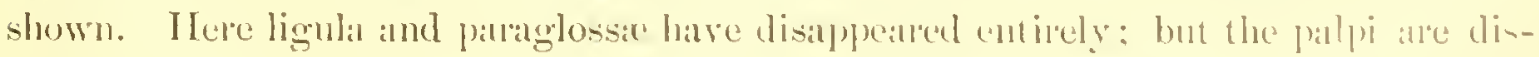
tinct and the curionsly developer hypophangme matis the beginning of the opening into the wepliagu-

A modification of this ype is tu be found in the Lepitopteria, where practically in all cases the palpi atone, attached to a plate of ratiable -ize and -hatpe, represent the labial itructures.

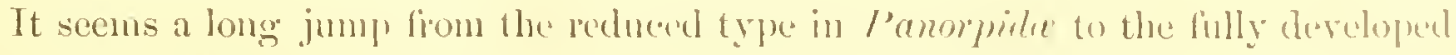
labium of the Apider: yet, exeept lor the fact that all the pillts alle mueh elongalted, 
there is no differenee from Andrence or I'olistes, which have been already studied. I have found no species which shows all the parts more fully developed thin Tenoglossa miminosa ( Pl. II, Fig. 15). Here all the parts are equally developed and all are functional; henee it makes a good starting point. The mentum is not shown in the figure except at the point to whieh the other parts are attached, and surmounting it eentrally, we find the ligula; here a mited, though extremely flexible organ. Lying centrally upon it, so as to close a groove, is the hypopharynx, in this case not easily separable from the lignla. Arising close to the central organ on each side are the paraglossie; almost as long as the glossa itself, flexible, unjointed, flattened and a little incurved at the margins so as to form, when closely applied to it, a partial shield for the ligula. Outside of all, situated at the outer margins of the mentum, are the palji. These are four-jointed; but the basal joints are enormously elongated in proportion to the terminal two, and they are also flattened ont, broadened and infolded, so that when at rest they cover and almost conceal the other labial parts, though not extending forward as fal as they. In this insect the structures just described are almost entirely covered by the maxille, and a transrerse section (Pl. II. Fig. 15\%) is interesting and instructive. It represents the struetnre at abont the middle of the combined maxillie and labium and illustrates the relative position of the parts.

The tendeney in the bees is toward a loss of the paraglossie, which shorten gradually mit they disappear altogether, as represented in al species of Bombus figured in Pl. III, Fig. 15. Every intergrade is represented in any good series of bee mouth larts, and in their rudimentary eonclition, without function, they appear in Bombers sp., represented on Pl. III, Fig. 6. The palpi retain their mniqne development, and in the figmre just cited are seen to be as long as the ligula itself, the basal two joints enfolding it almost completely, white the terminal joints are much reduced in size and set near the tip of the second joint, on the outer side. In other species these terminal joints are proportionately yet more reduced and are sometimes diflieult to find. The escential point to be noted is that at their best development the paraglosse are not jointed and that they tend to complete obsolescence in the mont highly speeialized types. The palpi in Bombus require a little further examination: Reference to the figure last cited will show a short segment between the mentum and the first long joint, and this is membranous in texture. The month parts in Bombus are folded when at rest and the hinge is at the mentum; henee the necessity for some such provision to enable the palyi to bend safely.

Now let ns assume that the ligula of this bombus beeame rigid and chitinized, and that the eughes of the palpi enfolding it became united to form a complete cylimler"; and then let ns examine Eriskalis tenure (PI. III, Fig. 5 ) in the light of this assump)- 
tion. First let me say that I have already shown that a thange from flexihle to rigicl ligulat is not uncommon. and the suggested muion of the palpi is a much lews violunt recunirement than that imposed he the eurent explanation of the Dipterous month. Raferring for a monent to P'l. I, Fig. 3, we see the entire month structure of Eristatio tenrix. Above is the mentum and submentum, very like the -tructure alreaty described for /'olistes and (ntirely homologons with it, and at its tip wo find arising in a gromp the structures further enlarged at Pl. III, Fig. 5. Centrally we find the now

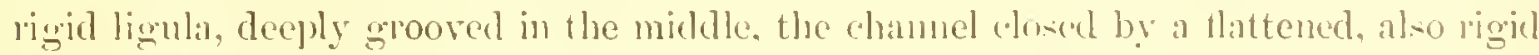
and chitinzed hypuphanx, loosely enveloping this centril ligulat is a more memlnanous "ylinder, eridently made ny of two bateral halves, 1 wo-jointed, and the tertminal joints separated or paired exeept at the base. Is in Romber the month of Eristalis is linged, and the joint is also at the bise of the ligula. The latter organ in so articulated as to allow of the flexion: but in the palpi we find again the provision alveady noted in Bombur - a tlexilule, membranous. pendo-segment. Now if we seetion the Bombes and Eristulis at the middle, we find the cuts alike. except that in Eristalis the palpi are completely united over the hypopharyns and closely approximated at the oppo-ite sille. If we section near the tip, the colts in both wates ane identical. That this mited structure in Eristalis is the mited labial pralpi secmin to me heyond donbt. In the first place, the point of origin is nomal, next to the lignlat and at the tip of the mentmm; and, secondly, it is a jointed organ and therefore cannot he paraglossa. It is in all point sthe strncture of Bomber. with the terminal joints lost and the two halve- mnited for the greated prot of the distanee. 'That the papts named mentum and submentum alre really snch, is proved by the fiact that the hypopharyns, which is not in dispute. orighintes from and that the aronphague originate within it.

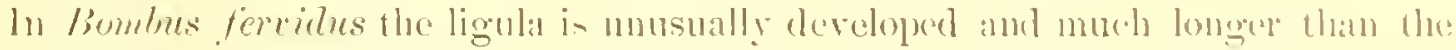

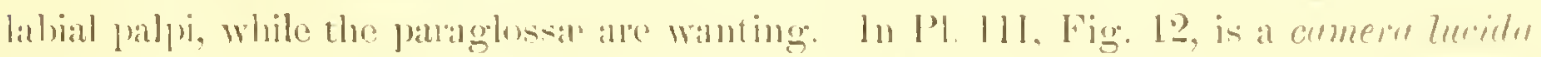

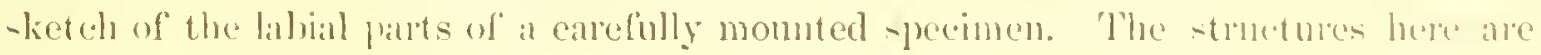
cxactly as nomally hetel when at rest, and myly the mentum is a little romand hy the corer glass on the hallow well. Now chitinize this whole structure thom whly, and

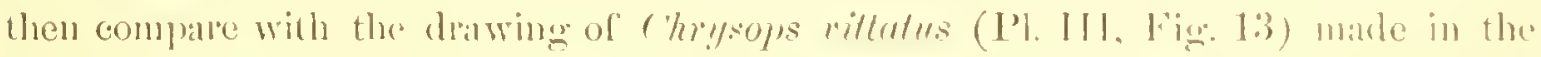
-ane way. The magnifications are dillerent, of course, the bomblus being drawn an -hort range with a four-inch lens while the Chrysops wats hawn at longrange muler a

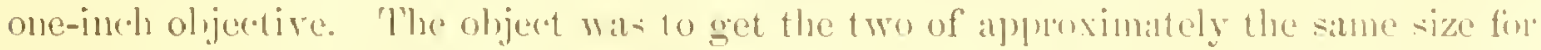

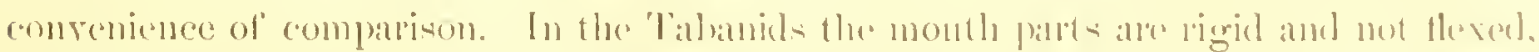
and uno solt of joint of hinge is reepured; henee the structures ape all rigidly unitul an the bave to the mentum. In Bomber fervidus the palpi atre reinforent by al heavier 
chitinons rod a little to one side of the middle, and just this sort of structure we find everywhere in the Tabanids, lying outside of the ligula at base, articulated to the onter edge of the mentum. This, in fact, first led me to suspect the true nature of the strueture. If now we section Bombus and Tabanus near base, the cnts will be alike, save that the palpi in the latter are united at one margin. If the cuts are made toward the tip, the sections are alike-lignia and hypopharynx alone appearing in both cises. We have then, in Chrysops also, a complete labinm, save that the paraglossic are absent and the palpi are mited on one edge.

In the Simulizde are many intcresting species with generalized month structures. and of these I have -tudied the "Buffalo gnat," from material kindly furnished by 1)r. Riley, an undetermined Simulizm sent me in numbers by Prof. Aldrich, and an undetermined little midge collected by me at Anglesea, N. J. The pecies are pratetically identical in the labial structures, and here again the mentum and submentum strongly recall P'olistes and other IIymenoptera. The hypopharynx is well developed and the ligula are nearly divided; but I have no satisfactory sections of this insect and the relations of the parts are not clear to me. At Pl. I, Fig. $1^{b}$, the labium of the "Buflalo gnat" is shown. In the speeies sent by Prof. Aldrich I sueceeded in getting a disseetion illnstrating the connection of the epipharynx with the mentum, and this is illustrated at PI. I, Fig. $1^{\prime \prime}$. This is really an exceedingly interesting specimen and it elears up the relation of the frontal prolongation of the mouth. That the strueture so labeled is really the epipharyux there is little room for doubt, and the location of the little, chitinous, toothed proeesses, and their character, leaves no donbt in my mind that they are mandibular mdiments-exactly as I claimed in my firet paper. That they can be dermal appendages, as has been claimed, does not seem reasonable to me. They are too highly ehitinized in comparison with their -nrroundings, and why shonld they so completely resemble miniature mandibles? I do not know of any ease of dermal appendagen of a similar character, and it is at least passing strange that such should be developed exactly where, normally, mandibular rudiments might. be reasonably expeeted.

The tendency in the piercing. Diptera is constantly in the direction of simplieity of labial stmctures. and so we gradually note the loss of all trace of acees-ory lathial structures, learing the ligulin and hypopharynx as sole representatives. In the tisilide there are no other attachments to the mentum, as shown in Pl. III, Fig. 1'.

These apparently single structures are sometimes interesting in section, as appears in Stomorys calcitrans, Pl. I, Fig. 11. Here the cut shows two crescent-shaped structures commected at one edge by the thimnest lind of a chitimens shell, and closed opposite by a hypopluryux, which is alnost tubular in structure. 
Fery interesting is the modification fond in the Empidu, illu-trating the extreme in the loss of parts: for here the hypopharynx is allow wanting, though the salirary duct remain., opening into the grooverl ligula, as shown in Pl. III, Fig. 2ّ. In this case the lypopharyx is replared by an extension and peculiar modifieation of the labmm. This sclerite is elongated so as to extend to the tip of the lahium, and is vely much dilited. somewhat bulh-like at its have. In Pl. III, Fig. 20, labrum and

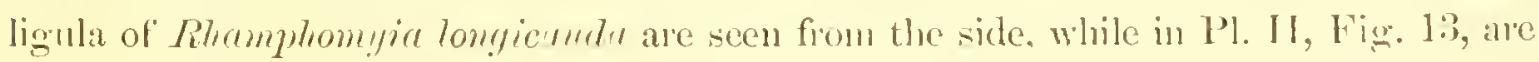
shown the same stunctures in Empris spectabitiv. The ederes of the labum are turned under sufliciently to leave a central chammet ju-t large comough to receive the ligulat. with which it then forms a clused tulne throngh which the frod is taken.

In most of the Muscid flies we lind a structure approximating fristatis with the labial pribi removed: and the prots may be longes, or shorter, or diflerently developed, while adding nothing to what has been already shown; they are, essentially, reduced piercing structures, no longer finctional.

We have, however, in eertain other species, whe the month structures ane short, very poorly developed labial structures. So in Hermetiu mucens (Pl. 1II, Fig. 14) the broad and lange mentum hears only a short, seoop-like ligula. The specimen from which the figure was made was somewhat distorted in monnting and the ligula is

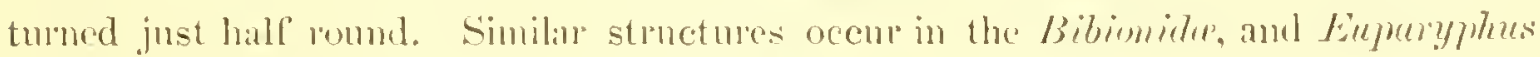
bellus (I'I. I, Fin. 12) is not essentially diflerent.

Ieretofore the hypopharyox has leen refered to maimly in species in which it was feebly dereloped and pliyed but a pa-sive part as a covering structure. It is sometimes a highly spectialized sensoly structure, thongh it valres greatly, eren when functional.

A very curions type is fommd in Bittures (Pl. 111, Fig. 4"), where it talies the form

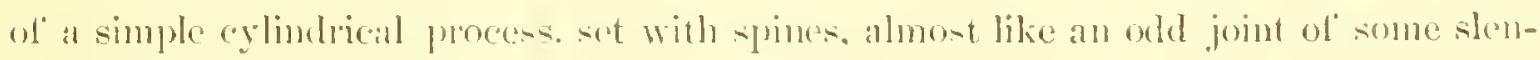

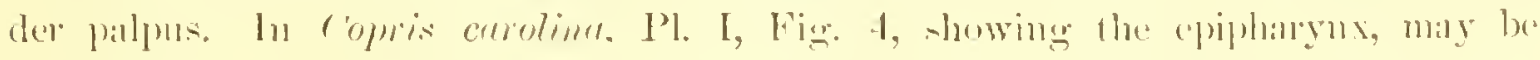

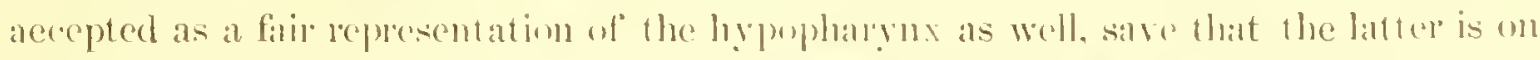

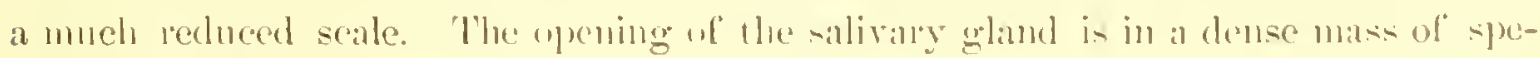

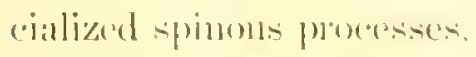

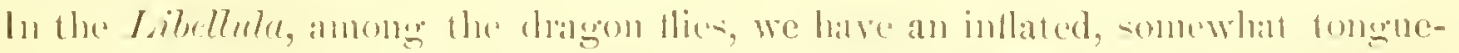

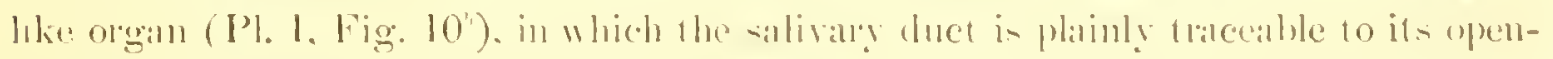

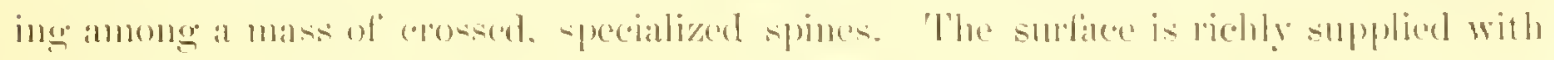
sensory pittings and tactike hairs. It is a great meditication from a strueture of this

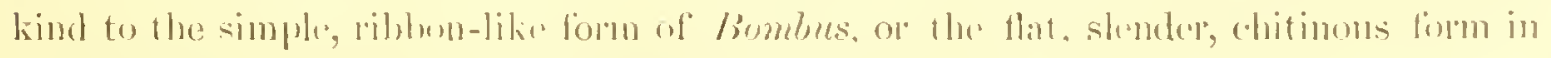

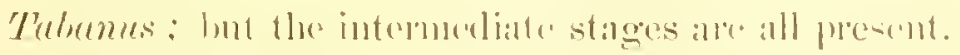

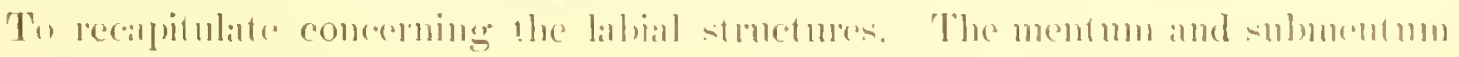


cover the erophigus. They may he united so as to form a single organ, and their tendency is to beeome intermal head structures. The ligula has at its hase the opening into the alimentary canal ; is rarely paired, may be rigid or tlexible, and has closely associated with it the hypopharynx, recognizable by the salivary duct which it shelters. The paraglosser arise on each side of the lignla or glossa, and may be chitinous or membranous. 'They are never' jointed. never developed for any specific mechanical purpose, and their tendency is to become obsolete. The labial palpi are essentially tarctile and never become medhanical save as they may form a covering or sheath for the ligula.

From the mont generalized type found in the Blatticlue the modification is first from a divided to a single ligula; next to a disappearance or obsolescence of the paraglosse ; later the labial palpi also di-appear, and finally the lyypopharynx is alio dispensed with. There is no break, and nowhere is there any violent change of structure or function.

We are now ready to take up the maxilla', which, though composed of a larger number of sclerites, are usually more easily understood in the urdinary type of mandibulate insect. The organ is usually paired and nerer $-o$ completely mited as the labial stmetures. The two parts are always external to the labium, which it is their tendency to enfold, and they never have any direct connection with the alimentiry canil. Thongh the maxillary structures tend to form a eovering or sheath for the labium and its appendages, there is never any intimate connection between them. No part of the maxilla ever unites with any part of the libim or with any of its appendage: The maxillie are essentially mechanical structures, and their range of variation is sufliciently great to meet the mont diverse possible demands made npon them. A distinct and fundamental characteristic is the fact that each set of celerites has its own peculiar possibilities and limitations, and once these are understood the most highly specialized type becomes simply explicable.

On PI. 1II, Fig. 17, is a copy of Prof. Comstock's figures of Ilydrophilus, showing the maxilla from both surfices, and these maly conveniently serve as a text to explain the scclerites composing it. At the base is the eardo or hinge, giving attuchment to muscles and tendons articnlating it to the head. It is to be noted that there is no firm or chitinous articulation to any head sclerite, and except by muscles or tendons no direct attachment. This we fornd the case also in the labium in the more specialized form, and in the Ifymenoptera, for instance, labium and maxille together are ensily dissected ont withont entting any but musenlar tis-ne, and without braking any chitinous connections w joints. 'Thi is in marked contrast with the mandibles which, when functional, are always firmly articulated by chitinous joints to the caternal 
head aclerites. Supported upon the caldo is the stipes or foot-stall, deriving its muscular attaclments largely from the cardo; but to -ome extent from the head itself, and this featmre is a valiable one. Surmomting the -tipes is a palpifer or palpus-bearer, to which is attached a palpus, varying in the number of its joints. 'This derives all its muscle- from the stipen in the typically developed maxillat. On the inner side of the -tipe- is attached the subgateal, deriving its muscles from the head in large part; and this bears a two-jointed gallea or hood. It is a matter of some importance to note that thi-galea i-never more than two-jointed under any cilreum-tances, and that the tendency is to maintain that number; though in many instances it i- reduced to one only. It $\mathrm{i}$ the most persistent as well als the most varialble of the maxillary structures, and i- present when any of them exist at all. Inside of the subgalea, and attached to it as a rule, i the lacinia or blade. which may or may not bear a digitus or finger. In the figures ju-t cited we find what may be termed a normal or proportionate development of all the parts, in which no one sclerite is muduly developed or -pecialized. Before attempting to study -pecializations it is important to note that, when carefully examined, the sclerite- atre seen to be arranged in three parallel serie- That is to -ay three -ejarable parts have grown together laterally, and thi- union bears with it the possibility of future di-mion or separation for special purpeses. We have an the inner -erie-lacinia and digitu-; as the middle, subgalea and galeal: and as the onter the cardo, stipes and palpifer with the attached palpus. Now if we examine some of the Nenroptera, e. \%., Siatis (PI. III, Fig. 16), we find this lateral arrangenent rery strongly marked, and it in easily moderstood that each of these parallel sets may harve their own peculiar limitations, and that each nay be separately and independently modificed.

But le-t thi--eem, after all, a fius-fetehed conclusion, let us examine the mitsillit of Bitlacus strigosns (Pl. Ill, Fig. $4^{b}$ ), and we fund almo-t cxilctly the lyypothetical

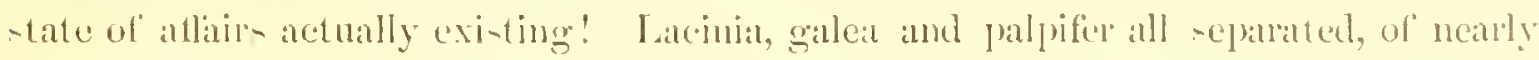
equal length, lut of quite different appealunce. The alppeaname of at tran-verse -eec-

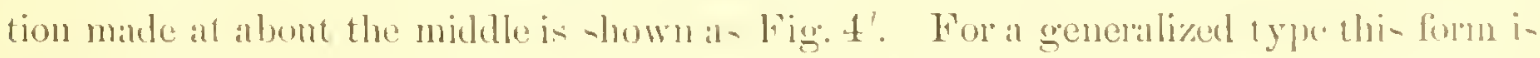

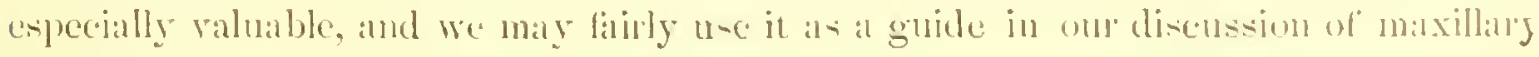
pessibilitice.

There in $n$ ab-olute rule in the matter, but u-nally the galea temds to become the dominant maxillary organ. In many Nenroptera, and e-pecially in their larral stages, the laciniate -tructure in be-t matred, a illu-trated in Pl. III, lig. ?, repre-entinge the ma villa of a Perlid lantrat Here the eqalea in reduced to a -ubordinate lank. and in many preslancoun- C'oleoptera it is truly palpitorm.

In many. Onthoptera the development of the galca ju-tifies the namme ly firming 
an almost complete hood orer the lacinia. This is well illu-trated in the maxilla of the oriental cockroach, Periplanetr orientalis, -hown at Pl. III, Fig. S. At thi-point a comparison of the figure ju-t cited with the galea of Simmlium (Pl. I, Fig. $1^{\text {r }}$ ) will prove intere-ting and instructive.

In the Hymenoptera the galea dominate throughont; no elongated palpifer i- erer developed, and indeed the maxillary palpi are cometime- almo-t indimentary in the Apicle, as shown at Pl. III. Fig. 15.

In Polistes, illustrated at Pl. II, Fig. 13: we find a common type of the lespridu. where the lacinia forms a small, blade-like structure. fiee for" almust its entire length, and the maxillie as a whole shelter a large part of the labium. In those eases in which the "maxillie" are elongated, the galea is usually the organ affected.

Thus in many Meloids among the Coleoptera we have the mouth parts elongated, and a study of the maxilla of Temognathe (Pl. III, Fig. 20) shows at once the -clerites concerned. IJere the lacinia is much reduced, and if we remove it altogether we have the normal Lepidonterous maxilla, which tends to a locking together to form a complete tube. Recently it has been found that in certain Lepidoptera the lacinia are actually present, and the figures which I hare seen indicate a structure in all essentials like that of Nemognatha.

While spealing of the Lepidoptera it may be well to cite Pronuba (Pl. III, Fig. 21), in which the palpifer is elongated in the female and highly specialized into a sensory and tactile structure, though unjointed. In a well-prepared specimen the point of origin is perfectly clear, and it is entirely homologons with the structure seen in Bittacus. In the male (PI. III. Fig. 19) the "tentacle" is not dereloped, though the palpifer is enlarged to some extent.

In the Apitu, anong the Hymenoptera, the lacinia disappear entirely in extreme eases, or are at least greatly rednced, while as ahready stated the palpi are sometimes scarcely visible. The galea, on the othel hand, is very prominently developed, and when at rest envelopes the ligulin and paraglossie almost completely. In PI. 1II, Fig. 15 , is represented the usual appearance of all the parts separated. while at l'l. 1I, Fig.

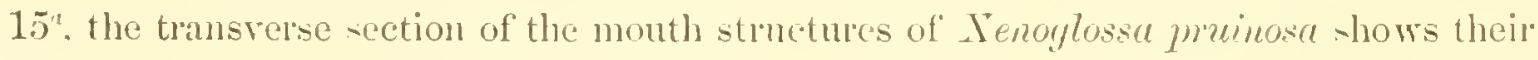
normal relation when at rent. It is seen that the galea alctually overlap somewhat at one margin, and a union along this line would be scarcely consillered al violent stretch of the range of valiation. Assume such a mion, eliminate the paraglossir which are organs tending to obsolescence, and then compare with the transection of Eristulis lenax (I'l. I, Fig. 3'). If the palpifer be eliminated firom this latter figure the cuts ane practically identical.

Returning to une ligure of Bombur. (PI. III, lig. 15), we note at the onter edges 
of the gallea a serien of ridges which, under a high power, look extremely suggertive of the structures found in the bibellu of Diptera, especially where, as for instance in Bombylin, the prendotrachea are imperfectly developed. These ridges vary much in the species; but are particularly marked in a little indiene near vicine, if not that species it-elf. Here we see (P'l. III, Fig. 3) the entire imner face clothed with at thin membrane which is crossed by numerous elosely set fine chitinons lines! I clain that this structure is the homologne of the psentotracheal structure in the Diptera, and that in the litter order it is in the galleal that the development ocem's, als it does liere in the Ilymenoptera. 'The relative diflerences in size are not of importance. Is to the particular use of this structure in Ludrenu I have no suggestion to make.

In the Proceedings Ent. Soc. Washington, Vol. III, Mr. Ashnead fignes on Pl. II, some rery suggestive mouth structures of parasitic IIymenoptera, of which that of" a Pteromalid is reproduced on Pl. IJI, Fig. 18. The central labium with it. attathed structures is much reduced in size, and the maxillice, bearing the well-dereloped palpi, are retuced to a single structure, the galea, resting upon what may be considered the stipes. Now if we bring these two palts of the maxillix a little more closely toguther, we have almost the exact structure seen in Bibio (Pl. II. Fig. 11b). The basal ring. bearing the palpi, corresponds almost exactly to the basal ring of I'teromalus except for size, while except that the surmoming galea ane two-jointed, the correspondence with the upper portion of the structure is equally markeal. 'The labium in Bibio is mueh like that figured in Pl. III, Fig. It, for Itermetia. and in Pl. I, Fig. 12, for Eetparylltes.

I am making no very risky statement when 1 assert that the sckerite to which the maxillatry palpi are attached must of necessity be maxillary; and further, it is crluilly silfe to say that no maxillary scterite can hear a labial appendage : and certainly not at

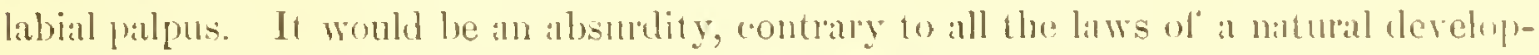
ment, for a modified labial palpus to hecome attactied to the selerite bearing also the maxillary pulpus; while if we consider it the two-jointed galeal, its position in nommal, requires massumption of change or character. and does not difler in any enential

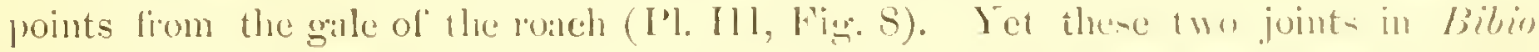
will, with a ridged membrane thrown over them, represent the labellate tip of the Muscid proboseis. "lhat - uch a ridged membrane is well within the range ol' gallear" variability we fonnd in the . Inderne near virine (I'l. III, Fig. :3).

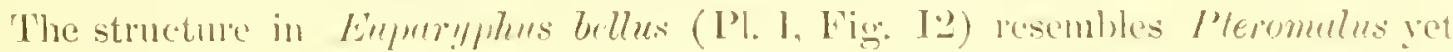
more coscly, in that a single ring only sumounts the segment bearing the palpun. In

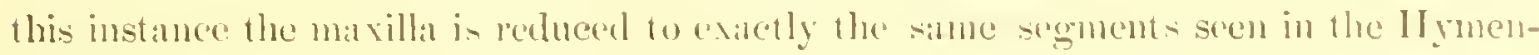
opteron, and logic demands that we recognize them ats the same. In this catse, huw- 
ever, the lower ring is complete-i. e., the two halves of the stipes have become muited. That it must be stipes is shown by the linet that it bears the palyms, and again the surmounting sclerite munt be maxillary al $\circ$ o.

There are other species allied to those already eited in which similar strnetures occur' but I need for the present call attention to only one more: a species of Olfiersia (PI. I1, Fig. 19). Ilere the ring is complete in front, but broadly open behind, and bears the chmby, single-jointed palpus. Surmonnting is a single selerite, rery much resembling in appearance that of /'teromalus, and undoubtedly homologous with it. Of course Olfersin is paranitic in habit, and the month parts are specialized for blond-ucking; but the sclerites eomposing them are neverthele-s derived from the same souree as in the "higher" types.

I have several times referred ineidentally to Simulium, and of this the galear structures are figmred (Pl. I, Fig. 1"). Dis-ecting the parts ont carefully we find an almost complete ring at the base, the stipes, to which the palpus and palpifer are attached. Surmounting thin is a pair of selerites, each almost a half cylinder, representing the subgalea, and bearing the two-jointed galea. Here again I claim that the three joints just referred to must be maxillary because they are direetly articulated to the sclerite bearing the maxillary palpi, and the labial strnctures are all shown at Fig. $1^{b}$.

A step in the direction of mion we find in the Anglesea gnat or midge-alio a Simuliid, to which reference has been alreaty made. Here we ree (Pl. I, Fig. $2^{\prime}$ ) the subgalea united mo-t of their length at one side, while the galear joints are yet free. The basal stiper is not figured because none of my specimens showed it clearly: but the palpifer, palpur and lacinias, as they are comnected with it, are show in the specimen.

In the Asilide we find another - nggentive strueture, studied in the light of the fict-already at ont. IIere we see, as illustrated P'l. III, Fig-. $1^{a}$ and $1^{b}$, the ba-al stipes well atereloped, mited posteriorly, but seprarated in front. The palpiler and its at tached palpus are situated at the sides, clearly articulated to the stipes, whose eharrancter is thes fixed. Attached to this stipes is a broad, infolded -tructure, mited behind but open in front: maxillany beeane of its attachment to the tipes, and subgailua from its location. It bears in orkerly -equenee the two-jointed galea of which the terminil joints are frece. The mpecies of the fsitide are litrge and easily di-sected, and the figure- were drawn from a speeies of Lapliriu. The attachunents alre but little different in the specics, and as the fignren illustrate the strueture from both front and reall, the position of the joints shond he cleall. 'These figures will be again referred to in another connection. 
In all the species heretolore cited the gallean joints we more on les- distinct and the psendotracheal system was little ol not at all developed. Is the face of the joints hecomes covered by a ridged membrane the texture of the entire structure changes. It becomes less chitinized, and the chitine is not evenly distributed, cansing sutmos s" hecome indistinct and poorly marked. Yet. keeping in mind the general line of vallittion, we can usually reach a contect conchusion.

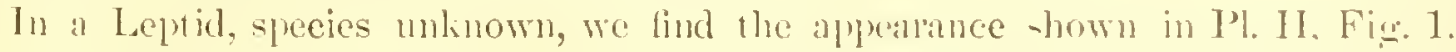

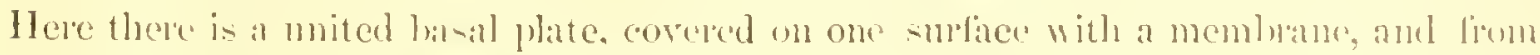
the chituon portion arias the palpifer with its attached palpus. Sumounting the

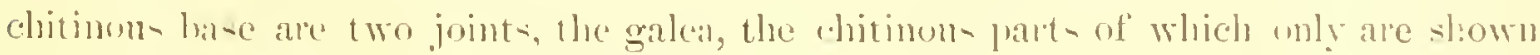
in outline, the balance of the sace being covered ly membrame. Here again the attachment of the maxillary palpus to the basal sclerite determines the maxillary challacter of all the scelerites directly articulated to it.

ln Ir-metia muen: (Pl. II, Fig. 16) the entire structure in much more memlnamous, yet the basal chitinou- plate is paired, and white the parts are shown in at di-turted position. the two galear foints and their relation to the basal. palpus-heringer structure is yet perfectly obrions. The other maxillary stuetures have completely disalpeared, while what is left of the labium is seen at Pl. 11I, Fig. 11.

The montls parts in some species of Tipulte are interenting, and a farle illustration of one of the "smub-nosed" species is seen at Pl. I, Fig. 5 . ITere the origin of the palpus at the immediate base of the chitinized part of the labella indicates its chatracter.

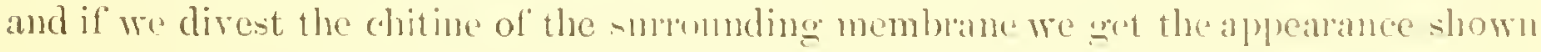
at Fig. 5. Practically we have a completely paired organ. the relations of which are perfectly simple when the confining and mimportant memblane is remuvent.

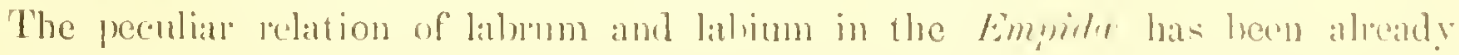

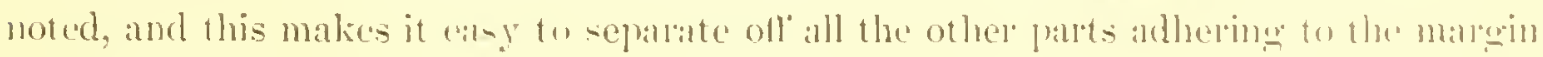
of the hearl, but mot in any way comected with the labinm. The relation of the parts

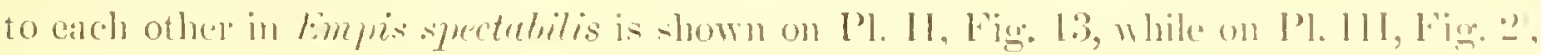

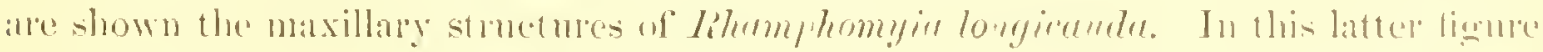

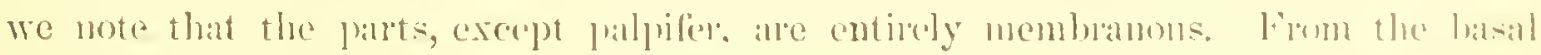

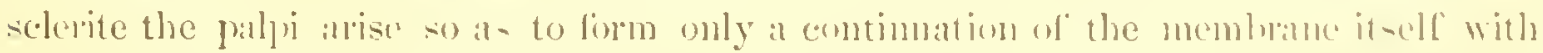

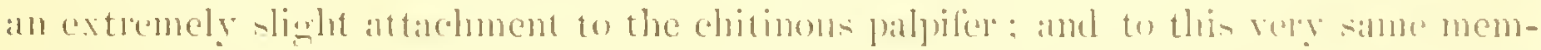

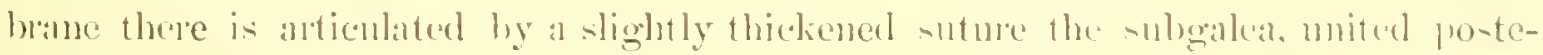

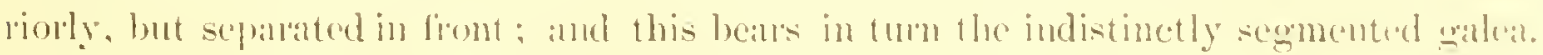

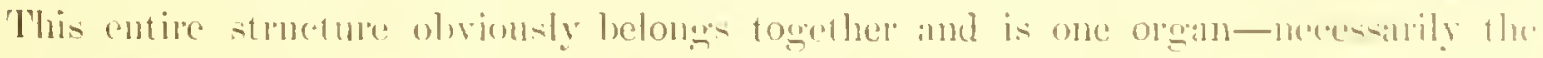
ma silli:.

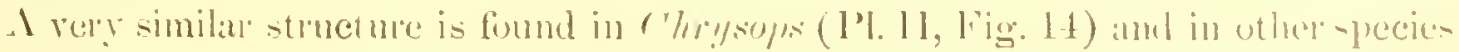


of the Tubanidu. Now it will be remembered that in this genus I showed the connection of all the labial parts with the mentum, where they normally belong; hence all the other parts must be, of necessity, maxillary. So we find also in Pl. II. Fig. 14. that the central labellate structure, two of the piereing structures and the maxillary palpi all arise firom a single mited basal sclerite, the stipes.

In Eristalis tenar (Pl. I, Fig. 3) those labellate structures are shown, turned aside to expose the labial structures. Here also I showed the presence of labial palpi in close comnection with the ligula and hypopharynx, normally attached to the mentum, and again it follow- that the other stuctures must he maxillany. Again also I must call attention to the fact that the palpi are mere continuations of the enveloping membrane, and that this membrane continues without heak to the tip of the labella. Unles- we are to believe that a continuous memlyane may give rise to both the maxillary and labial palpi, we camnot possibly consider the labella as labial structures.

I have now traced out what seems to me a continuous development of the modifieations of the subgalea and galea, and have shown, I think, that from /'teromalus in the Hymenoptera to Eristalis in the Diptera, a continuons chain may be construeted, requiring nowhere any change of character, function or loeation. Yo disassociation from other maxillary structures and no comnection with labial structures.

In taking "p the modifications of the palpifer. I am confined almost entirely to the Diptera, in which this sclerite is best developed. ln Bittacus I showed its development to an elongated structure of no particular type or function and of about the same texture as the galea. In I'romba I showed its development into a highly specialized "tentacle," tactile and sensory as well as mechanical in character. In the Diptera it is quite usually present as an elongated, rigid, chitinons organ adipted for' piereing. It occurs in all the piecing types and is present as a rudiment in many others. It undergoes a curions and interesting change in lunction as the Dipterous month changes from the prercing to the scraping or lapping type, and as it becomes flexed.

The simplest form occurs in those piereing Diptera in which the proboscis is not flexed. Thus in the 13uffalo gnat (PI. II, Fig. 9) it is a stont, semieylindrical piercing argan, enlarged both at base and at tip), at which latter point it is also toothed. The comnection of the palpus with the subgalea was already shown on Pl. I, Fig. 1", and this shows how the chitinons palpifer forms part of the combination. The palpifer allises, mmally, outside of the galca; yet at the tip it is fomd in comection with all the other piercing structures inside of that organ. How it gets there is illustrated in the Anglenea Simuliid ( (Pl. I, l'ig. 2'), where all the maxillary parts are show in proper commection, and it is seen last the palpifer enters the galear envelope in the 


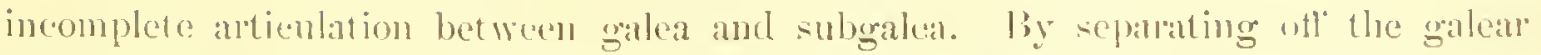
structures, the relation of palpifer and lacinia in Simmlium is illu-trated (on Pl. I, Fig. 1), and the convergence of the two at tip is not distortion, though perhalps a little exaggerated by pressure. 'The lesult of this change of position is that a section made neal the base of the proboseds woukd show as illustrated on Pl. L, Fig. 2', while one mate neater the tipe would show as in Fig. $1^{\prime \prime}$. Incidentally it will prove interenting to compare these sections with that of Bittucus strigosus (I'l. III, Fign. I'), leaving mit. ol" consideration the abmormal labinm of the latter. The resemblanee is perfect, and the resemblance expesses fully the actual condition of the matter. A very similill state of aflairs exists in the Asilide (Pl. III, Fig. $1^{a}$ ). Here the palpifere is the only maxillaty fiercing mo:m, and the figure itself shows eleaty how easily it wonk swing in-ide the ample space left in the subgalea for its entrance. 'The curviture of the oryan is such, also, that when in place it meets the central lignlar so als to form a solid puncturing organ.

So in Chrysops (I'l. II, Fig. 14) the structure is seen to be similan to that in simulium: lont here, as almost ererywhere else in the order, it is cylindrical or nearly $\rightarrow$, in malliker contrast with the lacinia. which is alwalys tlattened.

A- we get into types that have lost the piercing habit, the function of the palpiler fails ol changes. If the species have a short, nonthexed proboscis, it simply dwindles from disuse. So in Stratiomyin and in Leptis (Pl. II, Figs. 1 and 22) it simply forms al litte colitinom-appendage to the palpus-a mere remnant withent limedion. Ifom the other hand, the species are alle to thex the probosecis, another change takes plare. There is newled then some lever to which muscles for flexing an the attached, and no structure seeme to have leen -o easily ataptable as the palpifer. So we linel in the

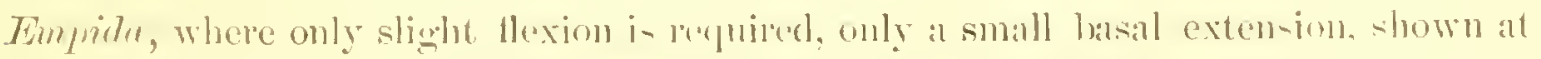

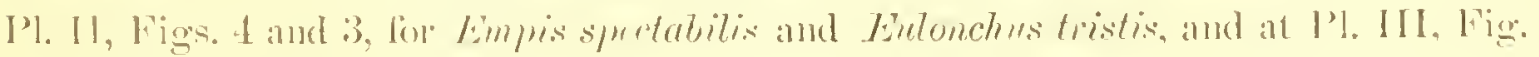

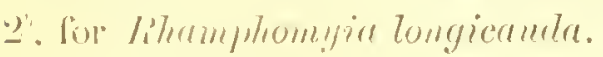

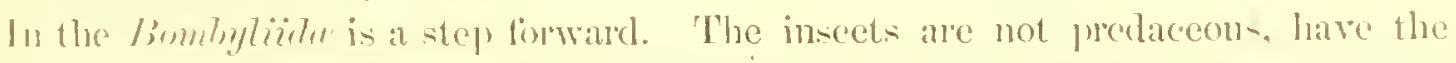
habit of hovering are thowers and nsing the proboses in fecting in that position. This repuires a much better' control, anut ats a result the basal catension is much better"

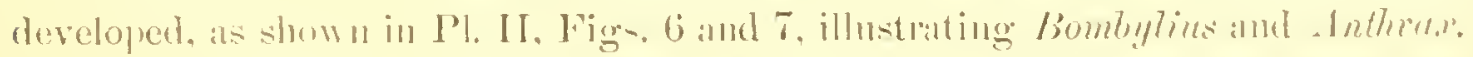

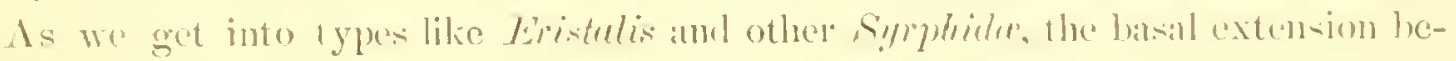

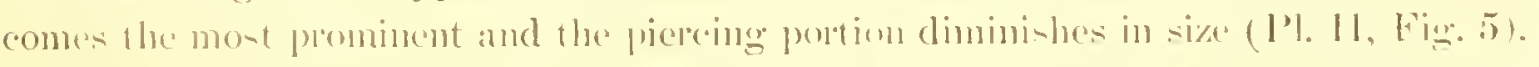

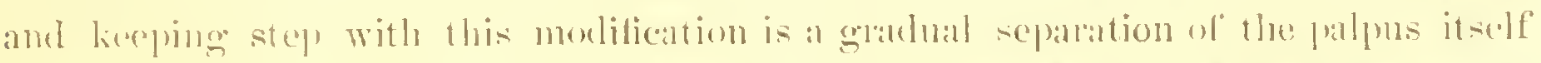

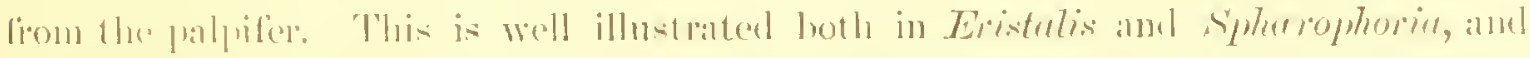

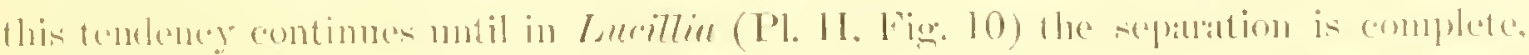

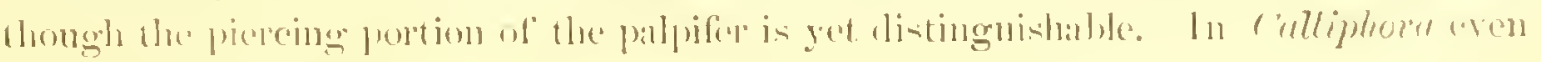


this disappears and the elitinom- rod in entirely disassociated from the palpus. Finally in Stomoxys calcitrme (Pl. II, Fig. 12) there remains nothing to indicate the existence of any relation between the slender chitinous rod and the distant maxillary palpus. It is not in the least strange that guesses as to the character of thi- strncture in Musra domestica should have been so often wide of the mark; thongh with a proper series as now shown, its origin is cletr.

There remains to be accounted for the lacinia. and this in the Diptera is the flat, blade-like structure generally identified as the mandible. It has been shown that while the lacinia in often the dominant organ in many manclibulate invects, the tendeney is, on the whole, to a decrease in size, ending in the Iynienoptera in its entire elimination. In the Diptera it is present in the blond-sucking species only, and it may be identified by it position and its relation to the other maxillary struetures. It has been sereral times referred to incidentally, and in the Anglesea Simuliid (Pl. I, Fig. $2^{n}$ ) its relation to the other maxillary part is shom. In Pl. I, Fig. 1c ${ }^{c}$, is illu-trated the comnection between the palpifer and lacinia in the Simulium -ent me by Mr. Aldrich. This comnection is not funciful but actual, and no sclerite so intimately connected with an admitted maxillate structure ean be anything but maxillary.

Again in Chrysops (Pl. II. Fig. 14) I have illustrated the fact that all the -tructures which I eonsider maxillary have a common origin. At Fig. 14" I show the lacinia alone, and it is to be noted that at the base it is modificd for attaclument with referenee to the palpus. Now unless thi is a maxillary sclerite, why should it be modified to accommodate the maxillary palpus:? Does it not seem rather absurd to believe that this can be a mandille brought to originate from one point with the palpifer and modified to allow it to envelope at base the maxillary palpus?

One of the mast serions difficulties in the way of the proper understanding of the month parts of hanstellate inseets has been the desire to provide for the mandibles on the theory that they are among the permanent structures. I I I camnot under-tand why this shonk necessarily be the case. When functional, mandibles are escentially chewing or biting organs, and when the insects do not require such structures, it -eems to me most natural that they shonld become obsolete: and that is exactly what has oecurred according to my reading of the facts. 'Their functional character never' changes; they simply dwindle from disure and gradnally di-appear. So we find them in the Lepidoptera as mere rudiments, eomected with a highly specialized maxilla; and in the Rhynchophora they are -ometimes mere remmant-, occa-ionally reversed in positim-exactly as I pointed them ont in simulium. I think that in view of all the evidence presented by me, none of the piercing organs of the Diptera ein lie eonsidered mandibles, and I camot even yet, after carefully weighing all that Dr. Packard 
has witten, -ce any reason why the rudinentaly structures at the tip of the labual extension in simmlimu alle not mandible-

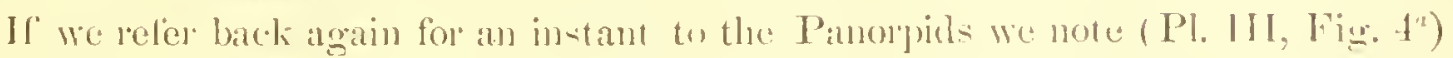

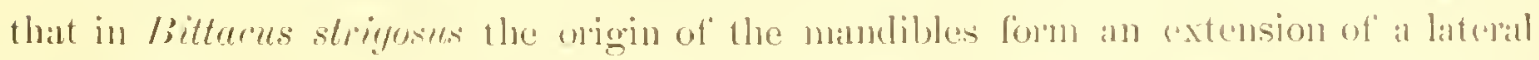
head sclerite, with the Labrum-epiphangus between them. In l'anome the month structures are much shorter, set on an immensely elongated stipes, and at the tip of the frontal extemsion of the head we again have the mandibles, mach reduced, with a small, lappet-like labrum-epipharymx hetwerse thems. Now the situation of the rudiments in Simulium corresponds almost exactly with that of the muloulsted mandihles

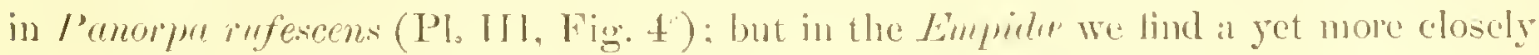
allied - Lmeture. I have alleady called attention to the peculiar elongation of the linont of the head in this fonnily, and now if we eximnine this at tip, in Empres spectabilis

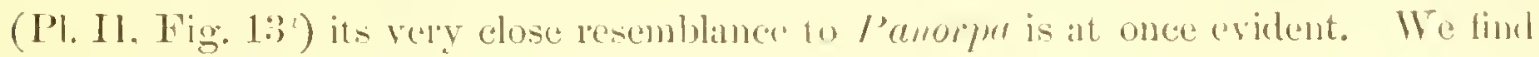
a central lappet-like structure with a sensitive sulface, which hook like and longlally should be the epipharym, and moving below it is a pair of appendages which, in my opinion, represent mandibles. They are membranous and poobably mot functional: lun

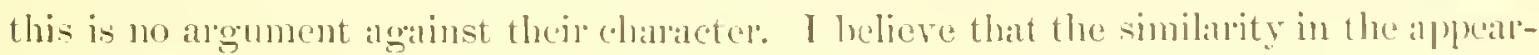

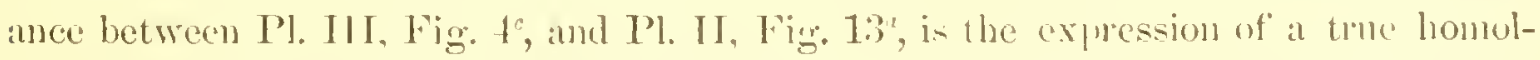
ogy, and that mandibles in the Diptera exist in no other form w situation. It is likely that of hel species, showing them much more perfectly, will yet be liscovered; but so indeed do I believe that labial palpii, properly comnected with the mentmm, will yet be found. so distinct in character that, even if not functional, their homolosy cammot be mistalicul.

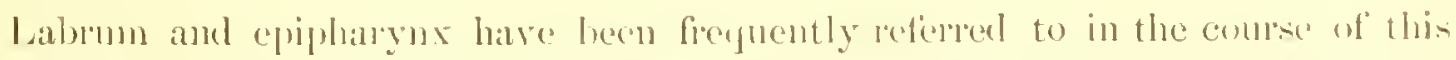
paper, and in the introduction the general relation of these two pants bats been "a-

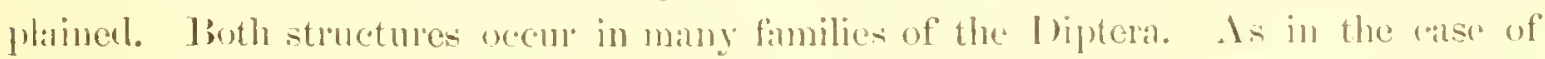

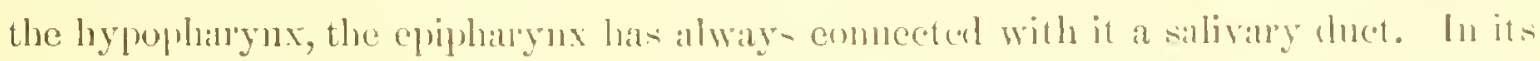

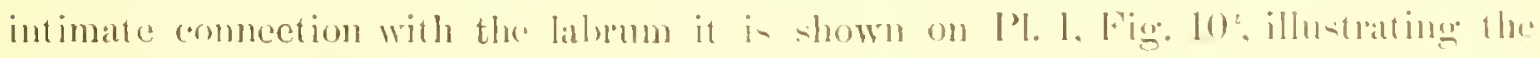

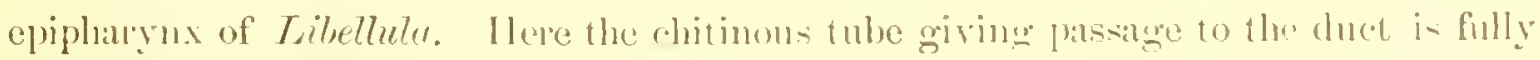

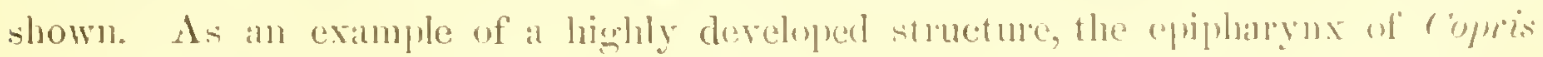

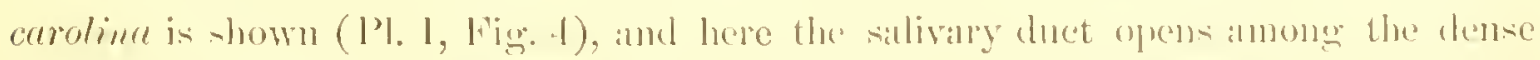

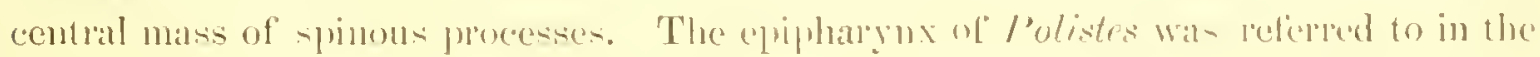
description of the labium, as wast that of fudveme in the connection. In the llemipr-

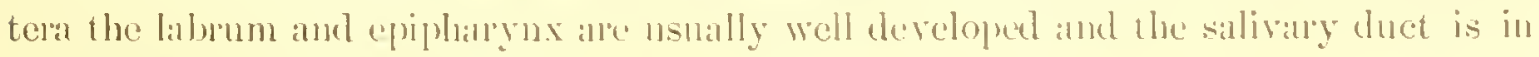
many eases vely well malied.

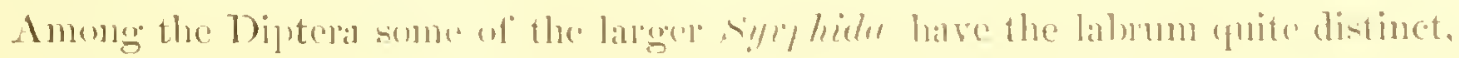

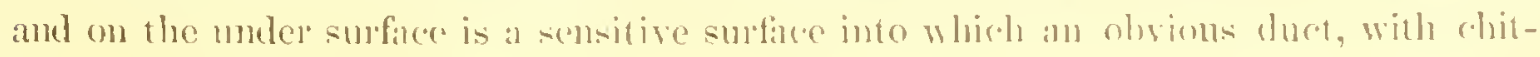


inous protecting margins, is led, as shown on P'l. III, Fig. 10. 1 much better developed organ, strongly resembling that in some of the Hemiptera, we find in the Asilide. (Pl. III, Fig. 1"), and here also the salivary duet is obvions. The structure in , rimulimm has been already referred to, as has that in the Empicte.

To recapitulate concerning the maxillat: The sclerites form three series, each of which has its own possibilities of derelopment. The lacinia never develope into anything other than a chewing or piercing organ and always arises inside of the galea. The galea varies in the direction of forming an enveloping organ for all the other month parts, and the subgalea eventually mites along me margin for that purpowe There is a tendency to develop a ridged membrane on the imner surface of the gralear joints which culminates in the psendutrachea of the muscid labella. The palpifer has a small range of development, from an unjointed. flexible, tactile organ, to a rigiel, piereing structure: and as this becomes nseless, to a process lin the attachment of muscles used to flex the proboscis.

It remains only to acknowledge the assistanee received fiom my entomolugical friends. Dr. S. W. Williston has from time to time sent me snch specinens as I thought might help me; Mr. C. W. Johnson has given me unmerons species of fanilies seleeted because of ajparent differenees in the month stmeture; and to Mr. .T. M. Aldrich I owe many other species in some nmmbers, among them the Simulied alrealdy referred to. Mr. E. P. Fell kindly sent me speeimens of I'anorpa and Bittacus, which enabled me to make a mueh more complete study of these insects than would have been otherwise possible. To all these gentlemen, as well as to the others who hare in any wise aided me. I desire to express my thanks.

Coneerning the fignes-most of them are camere lucidu drawings. A few are drawn from micro-photographs, assisted by the specimens themselves. The figures of transections are largely mate from actual preparations; some are restrawn fiom other sonres, while a few are illeal. 


\section{Explanation of the Plates.}

The lettering of the parts, the same throughouf, and the abbreviations, are as follows: Lbr, habrum; rpi, epipharyux (the two sometines combined as $l u r \cdot p i)$; ml, mandible; car, cardo; st, stipes; jfr, palpifer; mp, mixillary palpus; gul, galen; sg, subgalea; lac, heinia; dig, digitus; sm, subnentum; m, uncntum; gl, ligula or glossa ; per, paraglossil; lp, labial palpi ; hyl, hypopharynx.

\section{rlate I.}

Fig. 1. lautlalo gaat. 1", galear structures with palpi attached ; 1b, Jabial structures; 1s, lacinia and pa?pifer of Simulinm from Alirich; $l^{d}$, lahrum anl labinm of Simulium from Aldrich; le, transverse section through milclle of moutla of Bullillo gart.

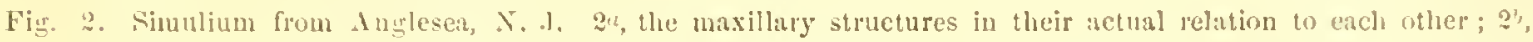
transverse section of mouth parts toward the hase of sulugalea.

Fig. 3. Mouth parts of Eiristalis tente. $3^{\text {th }}$, trinsverse section of same at the middle of subgalea.

Fig. 4. Copris carolina, epipharyux.

Fig. 5. Mouth stunctures of Tipula $-p$; 5 , the chitinous parts of the same.

Fig. 6. Copris crrolina; labial strnctures dissected out and seen from side.

Fig. 7. Copris earolina; chitinous part of under sille of head.

Fig. S. Copris curoline; mathdible with the selerites named and homologized.

Nig. 9. Andrene vicine; lillial structures, with part of epipharynx attached.

Fig. 10. Libellult sp. the the epipharynx; $b$, the hypopharynx.

1'ig. 11. Stomoxys culcitrans; trinsverse section through the midule of the ligula.

Fig. 12. Mouth pirts of Euparyphus bellus.

\section{flute II.}

Fig. 1. Maxillary structure of Leptis sl?.

Fìr. 2. Palpifer of Stratiomyiu.

Fig. 3. Palpifer of Eulonchus tristis.

Fig. 4. Palpifer of Empis spictabilis.

Fig. 5. Pajpifer of Spharmhorie cylinalrice.

Fig. 6. Pillpifer of Bombylius.

Fig. 7. P'alpifer of Anthrax.

Fig. S. Palpifer of Chrysops vithetus.

lig. 9. dalpifer of simulium.

Fig. 10. J'illpifer of Lucillir.

Fig. 11. Palpiter of Culliphore.

Fig. 12, I'alpifer of stomoxys.

l"igs. 10 to 12 inclusive wore aceilentally reversed in making up the plate.

Fig. 13. Nonth parts of Empis spectabilis. 13", elongated head structure at tip, showing mandibles and epipharyn , $1 ; b$, trinsverse section at mildle of sulugaleal.

Wig. 14. Mouth parts of rhrysops ritutus showing maxillary structures attached together. 1.1', the lacinia : 1.th", [all. jifer and palpus ; 14, transverse section at midclle of galea.

l'ig. 1.5. Labial structures of Tenoglossa pruinost. a, transverse section at about midlle.

l'ig. ]6. Labial structures of Periplanctu orientulis.

Nig. 17. Maxilary structures of Hermetia mucens.

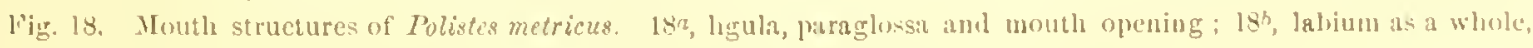
witlı epiplarynx attached; $18 \mathrm{c}$, maxilla.

lig. 19. Maxillil of Olfersia. 19z, seen from front; 19', seen from behind or below. 


\section{I'late III.}

Figg. 1. Mouth structures of Asilida-Laphrin sp. a, maxilla from frout ; $b$, saue from behind ; $c$, labium; $d$, lah. run ; e, transverse section of mouth at junction of galea and sulbgalea.

Fig. 2. Mouth struetures of Rumphomyia longicuuda. a, the labium; $b$, maxilla ; $r$, extension of front of head; l, relation of this extension to the labium.

Fig. 3. Galea of an Andrena allied to vicina.

Fig. 4. Mouth parts of Bittacus strigosus. a, mandibles and labrum; $b$, maxilla and labium; $c$, mandibles aud labrum-epipharynx of Punorpa rufescens.

Fig. 5. Labial structures of Eristalis tentx. 50, 1ransverse section at about middle; 5 , same at about tip.

Fig. 6. Labial structure of Bombus sp. $6 a$, transection at about midlle; $6 b$, same made near tip.

Fig. \%. Labium of Hurpalus calignosus.

Fig. 8. Maxilla of Feriplaneta orientalis.

Fig. 9. Maxilla of Perlid larva.

Fig. 10. Epipharynx of Eristalis tenax.

Fig. 11. Mouth parts of Bibiosp. a, maxilla from hehind; $b$, same in front; $c$, transection male near the base.

Fig. 12. I abium of Bombus fertidus; the transections are lined to the portions referred to.

Fig. 13. Labium of Chrysops vithatus; the transectious are lined to the parts referred to.

Fig. 14. Labinm of Hermetia mucens.

Fig. 15. Maxille and labium of Bombus, showing the relation of the parts to each other.

Fig. 16. Jaxilla of Sialis.

Fig. 17. Maxilla of Dydrophitus from upper and lower surface, redrawu from Comstock.

Fig. 18. Maxilla and labium of Ptcromalus, redrawn frotu Ashmead.

Fig. 19. Maxilla of Pronuba, male.

Fig. 20. Maxilla of Femognatha.

Fig. 21. Maxilla of Pronuba, female.

Fig. 22. Month parts of Locusta fron Kolbe. i, labrum; ii, mandibles; iii, maxilla ; iv, labium. 


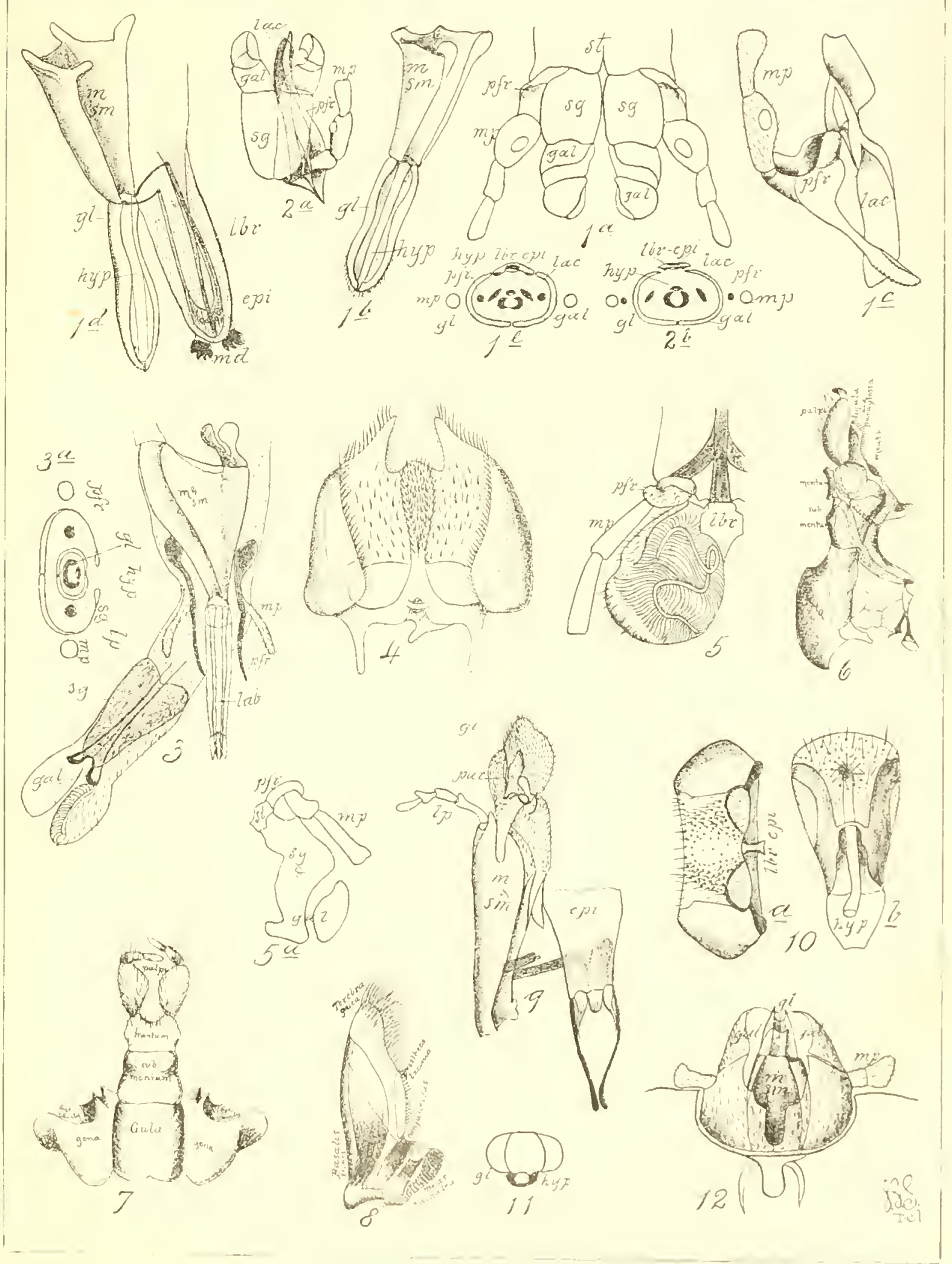




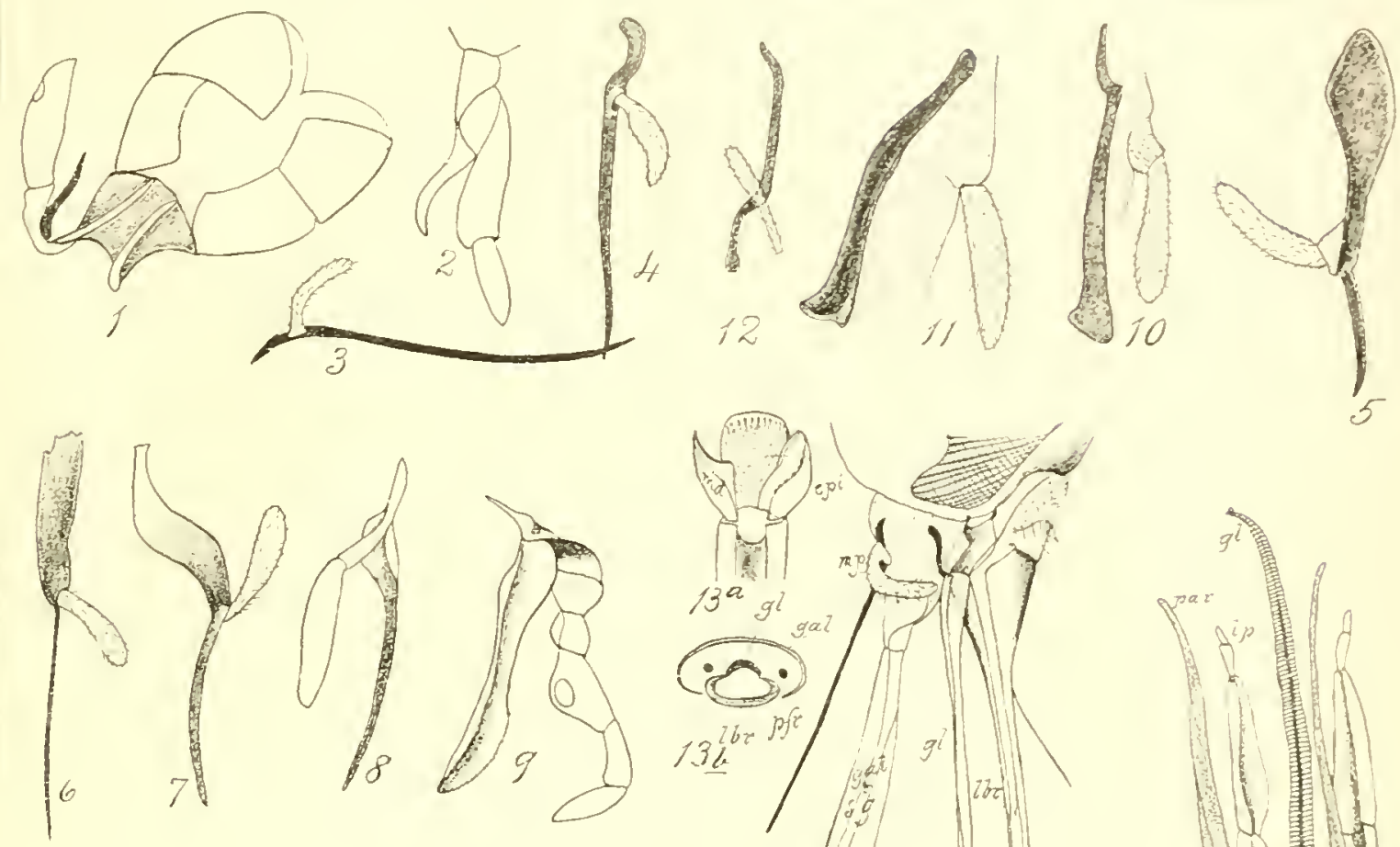

5
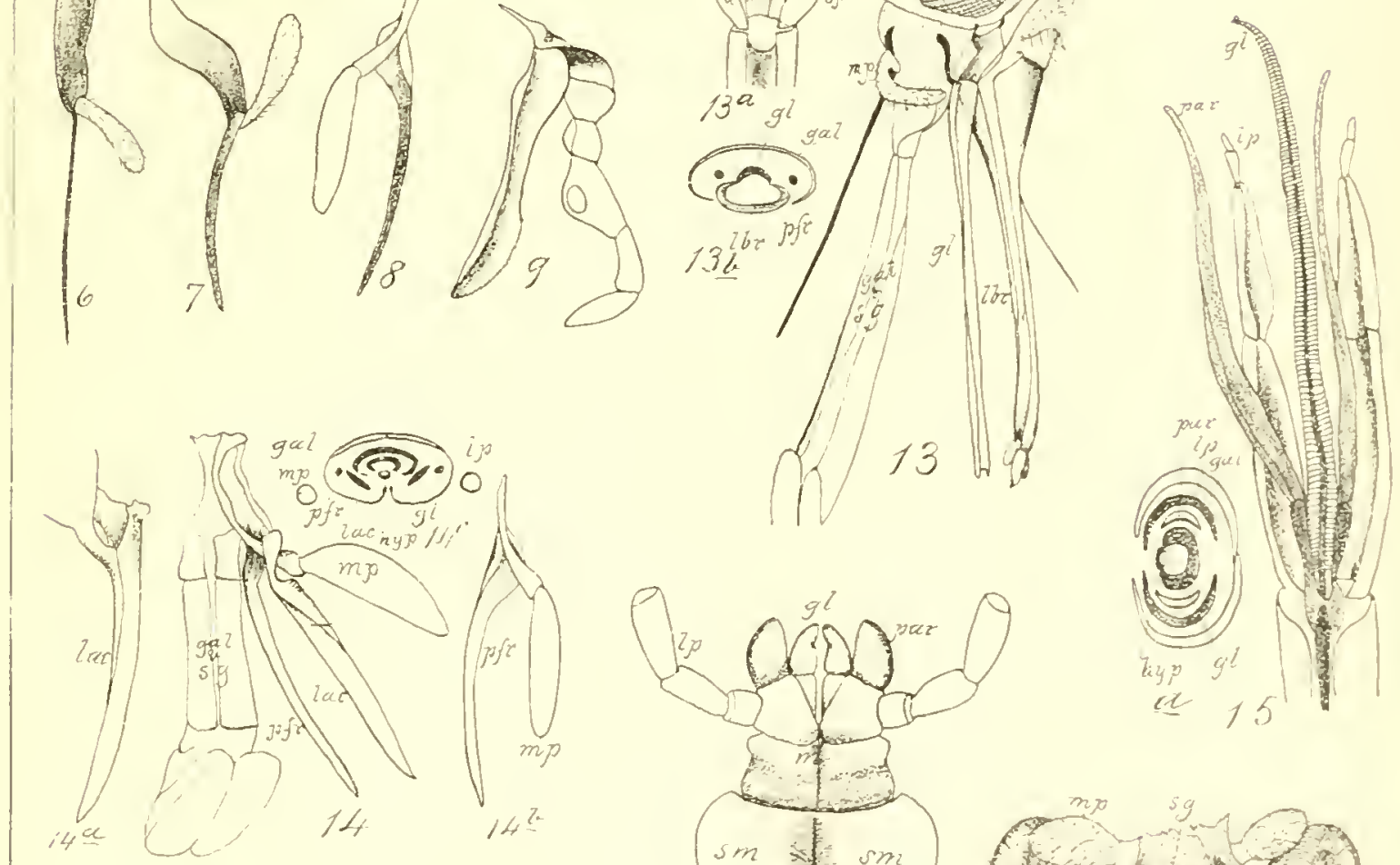

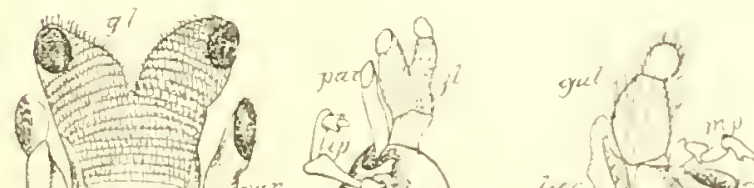
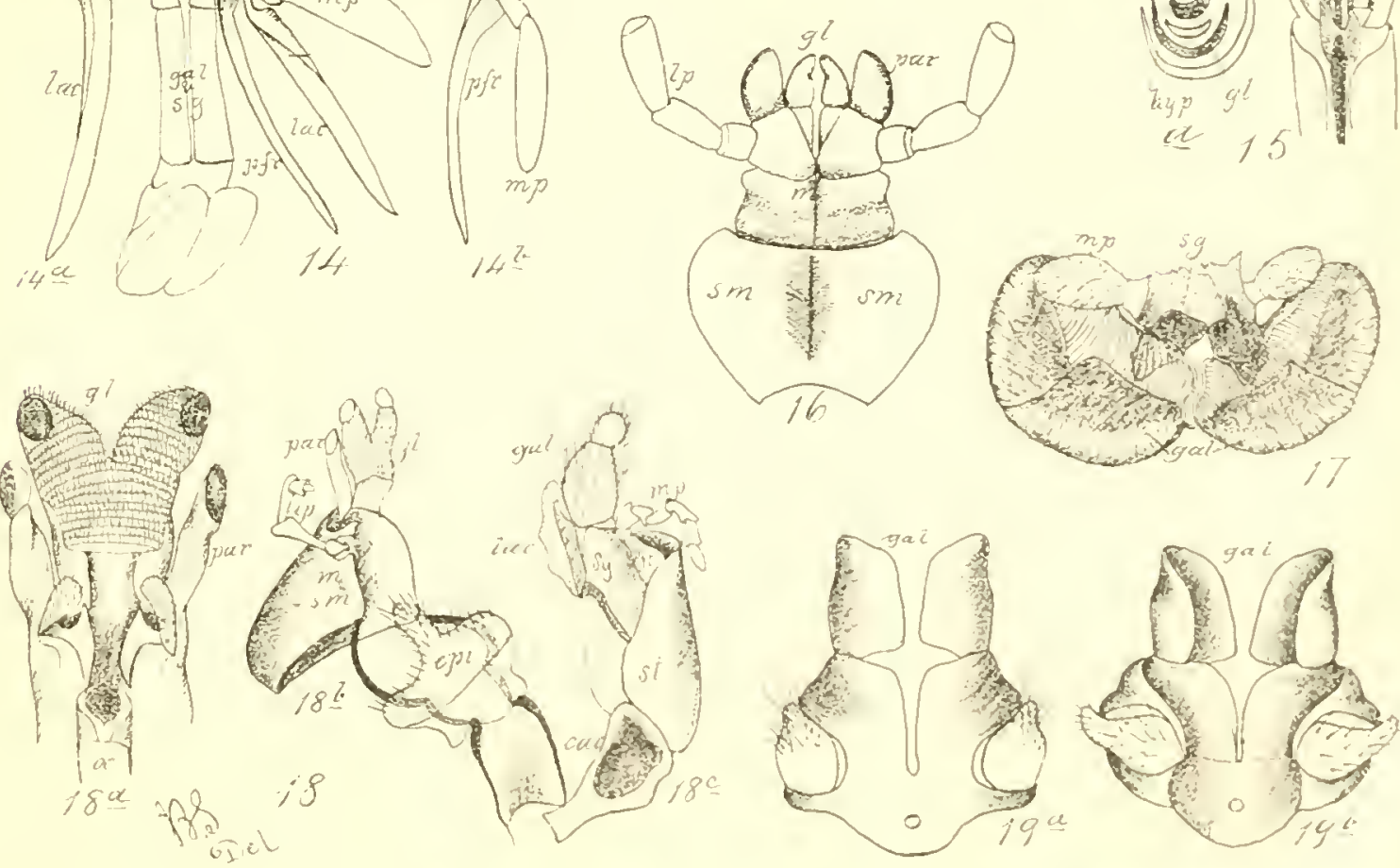



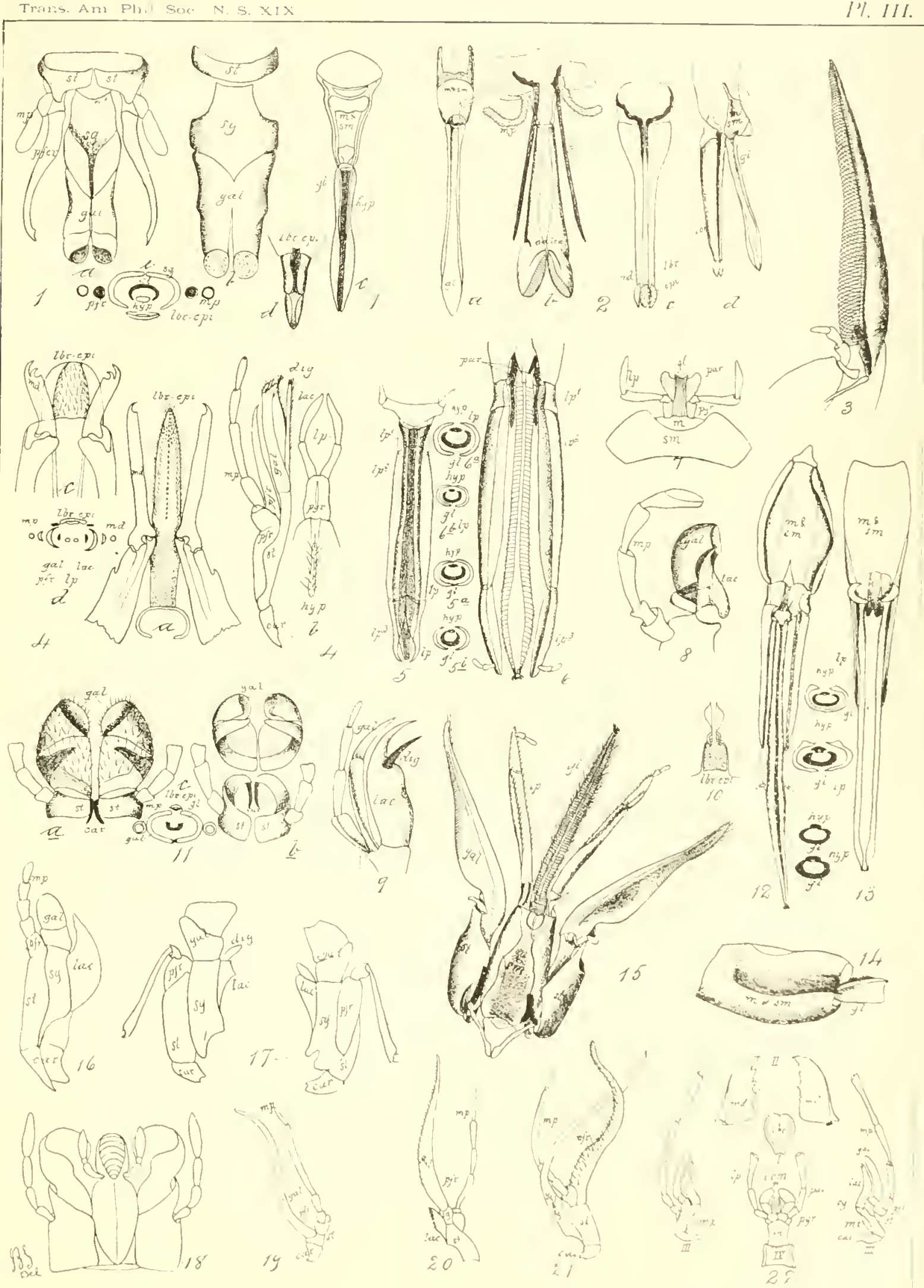




